\title{
Bioaccumulation of Cadium, Copper, Zinc, and Nickel by Weed Species from Municipal Solid Waste Compost
}

\author{
Shulan Zhao, Lian Duo* \\ Tianjin Key Laboratory of Animal and Plant Resistance, College of Life Sciences, \\ Tianjin Normal University, Tianjin 300387, P.R. China \\ Received: 2 March 2014 \\ Accepted: 3 August 2014
}

\begin{abstract}
A field experiment was conducted to evaluate the efficiency of native monocotyledonous weed species for heavy metal phytoextraction from municipal solid waste (MSW) compost. Results showed that total contents of cadium $(\mathrm{Cd})$, copper $(\mathrm{Cu})$, and zinc $(\mathrm{Zn})$ in MSW compost generally exceeded the maximum levels indicated in Chinese regulations, except nickel (Ni). The general trend of metal accumulation in plants was $\mathrm{Zn}>\mathrm{Cu}>\mathrm{Ni}>\mathrm{Cd}$ and accumulation differences depended on plant species. Except for Carex tristachya, the Cd, $\mathrm{Cu}$, and $\mathrm{Ni}$ contents in above-ground parts of four other species were within the normal values in plants. Most plants accumulated target metals mostly in the roots. With BCF and TF values $>1$, Carex tristachya displayed some Cd-hyperaccumulative characteristics, being classified as potential species for phytoextraction of $\mathrm{Cd}$ from MSW compost. Other species can be considered adequate candidates for metal stabilization and soil conservation.
\end{abstract}

Keywords: monocotyledonous weeds, MSW compost, phytoextraction, heavy metal

\section{Introduction}

With the rise in population and economic development, municipal solid waste (MSW) is being produced massively, especially in developing countries. Chinese cities generate more than 100 million tons of MSW every year [1]. A lot of attention has been paid to the disposal of large volumes of MSW in China. Composting has proved to be an effective way to reduce large quantities of MSW and accelerate the biodegradable components to decompose and stabilize, for completely sustainable recycling [2]. The use of MSW compost on agricultural land enables the recycling of valuable plant nutrients $\mathrm{N}$, $\mathrm{P}$, and $\mathrm{K}$ plus micronutrients and organic matter, resulting in beneficial effects on soil properties such as water-holding capacity, aeration and porosity, and plant

*e-mail: duolian_tjnu@163.com nutrition [3-5]. However, MSW compost often contains potentially toxic metals that can cause phytotoxicity, soil contamination, and accumulation in plant and animal products [6-8]. Therefore, toxic metals should be cleaned up before MSW compost application on agricultural land.

Phytoextraction, which uses appropriate plants to remove metals from contaminated soils, has gained popularity due to its low cost and comparatively lower damage $[9,10]$. Early studies mostly focused on hyperaccumulator plant species and more than 400 species of hyperaccumulators have been documented in the world [11, 12]. Though hyperaccumulators can accumulate exceptionally high quantities of metals, they are not practically used in phytoextraction partly due to the fact that the hyperaccumulator plants are relatively rare, have limited response to various metals, and maintain a slow growth rate [13]. Thus identification of more effective hyperaccumulators is of 
vital importance for successful phytoextraction. According to Robinson et al. [14], a plant used for phytoextraction should be fast growing, easily propagated, and capable of accumulating the target metal. Weed species usually own such inherent properties as strong tolerance to various adverse environmental conditions, fast growth, high reproduction, and biomass that can increase sharply under favourable conditions [15]. Ghosh and Singh [16] indicated that Ipomoea carnea was more effective in removing $\mathrm{Cd}$ from soil than the hyperaccumulator Brassica juncea. Solanum nigrum, Conyza canadensis, and Rorippa globosa were found to possess basic characteristics of a Cd-hyperaccumulator [17, 18]. Muhammad et al. [19] investigated wild plants growing around $\mathrm{Pb}-\mathrm{Zn}$ sulfide terrain in the Kohistan region of northern Pakistan and found that Plectranthus rugosus, Rumex hastatus, Fimbristylis dichotoma, Heteropogon conturtus, and Myrsine africana were the best heavy metal accumulators. The main objectives of our research were to:

(1) Estimate the potential of five monocotyledonous weed species for phytoextraction of heavy metals from MSW compost

(2) Assess the contents of several heavy metals $(\mathrm{Cu}, \mathrm{Cd}$, $\mathrm{Zn}, \mathrm{Ni}$ ) and their distribution in different plant parts.

\section{Materials and Methods}

\section{Description of the Study Area}

The experimental site is located on the campus of Tianjin Normal University, China $\left(117^{\circ} 2^{\prime} \mathrm{E}, 39^{\circ} 13^{\prime} \mathrm{N}\right)$. The area is characterized by a warm and semi-humid continental monsoon climate. The average annual temperature is $12.3^{\circ} \mathrm{C}$. The warmest and coldest months are July and January, with mean temperatures of $26^{\circ} \mathrm{C}$ and $-4^{\circ} \mathrm{C}$, respectively. The average annual precipitation is around 550-680 $\mathrm{mm}$, and summer precipitation accounts for about $80 \%$ of the annual precipitation. On the basis of the investigations of the yearly averaged sunshine duration from four meterological stations [20], Tianjin has enough sunshine with annual sunshine duration of $2500-2900 \mathrm{hrs}$. There is no frost in 196-246 d in each year.

MSW compost collected from Tianjin Xiaodian compost plant was spread in the experimental site to a depth of $20 \mathrm{~cm}$. Turfgrass was originally established in the site. Because plenty of weed propagules are widely distributed in the surrounding soil, weed species gradually invaded the experiment site from the outer environment. Weeds in the site experienced germination and growth, and were harvested after their physiological maturity (about 5 months).

\section{Sampling and Analysis}

The selected plants commonly found in the local agricultural ecosystem were monocots: Digitaria sanguinalis, Echinochloa crusgalli, Carex tristachya, Setaria viridis, and Cenchrus echinatu. Once collected, plant samples (3 replicates) were thoroughly washed with tap water and finally rinsed with deionized water, and then divided into roots, stems, and leaves. All the fractions were oven dried at $105^{\circ} \mathrm{C}$ for half an hour and then at $80^{\circ} \mathrm{C}$ for about $24 \mathrm{hrs}$ to a constant weight. Ground samples $(\sim 300 \mathrm{mg})$ were digested by heating $\left(140-160^{\circ} \mathrm{C}\right)$ in mixed acids of nitric acid and perchloric acid (2:1). After cooling, the digest was diluted to $25 \mathrm{~mL}$ and analyzed for heavy metal $(\mathrm{Cd}, \mathrm{Cu}, \mathrm{Zn}$, $\mathrm{Ni}$ ) concentrations by inductively coupled plasma-atomic emission spectrometer (ICP-AES). The compost samples were air-dried and crushed and passed through a 2-mm sieve for chemical analysis. Compost $\mathrm{pH}$ was measured by glass electrodes in 1:2.5 water extracts [21]. Organic matter content was determined by the method of $\mathrm{K}_{2} \mathrm{Cr}_{2} \mathrm{O}_{7}-\mathrm{H}_{2} \mathrm{SO}_{4}$ oxidation [22]. Total nitrogen content of compost samples was analyzed using Kjeldahl digestion [23]. Available P was measured by sodium hydrogen carbonate solution-Mo$\mathrm{Sb}$ anti spectrophotometric method. Compost samples were wet-digested with a mixture of aqua regia and $\mathrm{HClO}_{4}$. The contents of heavy metals in the digests were determined by ICP-AES as indicated for plant samples.

\section{Statistical Analyses}

The data reported in this paper were processed with Microsoft Excel 2003 and SPSS statistical software (SPSS 11.5; Chicago, IL, USA). One-way ANOVA was carried out by considering the different plant species as independent variables at a significant level of $\mathrm{P}<0.05$. Ducan's multiple range test was used to compare means.

\section{Results and Discussion}

\section{MSW Compost Properties and Metal Concentrations}

The MSW compost used as plant culture medium was analyzed. The basic properties were as follows: $\mathrm{pH} 7.60$, organic matter $12.0 \%$, total N $5.10 \%$, available P 77.9 $\mathrm{mg} \cdot \mathrm{kg}^{-1}, \mathrm{Cd} 1.34 \mathrm{mg} \cdot \mathrm{kg}^{-1}$, Cu $304 \mathrm{mg} \cdot \mathrm{kg}^{-1}, \mathrm{Zn} 457 \mathrm{mg} \cdot \mathrm{kg}^{-1}$, and Ni $26.2 \mathrm{mg} \cdot \mathrm{kg}^{-1}$. The compost was slightly alkaline, in agreement with the results of Jordão et al. [21]. The higher $\mathrm{pH}$ is attributed to high concentrations of exchangeable bases in compost [24]. Soil pH is a major factor influencing the availability of heavy metals. In most cases, increasing $\mathrm{pH}$ declines metal availability [25]. Consistent with other research [21], higher nutrient contents of organic matter and total $\mathrm{N}$ were found in compost. Organic matter contains large quantities of plant nutrient that act as a slow-release nutrient storehouse.

When comparing our data with the maximum metal concentrations allowed by Chinese regulations for agricultural soils with $\mathrm{pH}>7.5$ (GB 15618-1995), the total contents of $\mathrm{Cd}, \mathrm{Cu}$, and $\mathrm{Zn}$ in compost exceeded the allowable limits $\left(0.6,100,300 \mathrm{mg} \cdot \mathrm{kg}^{-1}\right.$, respectively), while Ni content was below the permissible level $\left(60 \mathrm{mg} \cdot \mathrm{kg}^{-1}\right)$. Therefore, the compost was contaminated by $\mathrm{Cd}$ (2-fold above the limit), $\mathrm{Cu}$ (3-fold above the limit), and $\mathrm{Zn}$ (1.5fold above the limit), and required a remediation process. 


\section{Metal Concentrations and Partitioning in Plants}

Metal $(\mathrm{Cd}, \mathrm{Cu}, \mathrm{Zn}, \mathrm{Ni})$ concentrations were determined in the roots, stems, and leaves of 5 monocotyledonous weed species growing naturally on the compost and the obtained results are shown in Fig. 1. The Cd concentrations were generally very low for all the investigated plants, which may be partially due to the fact that the level of cadmium in the tested compost was not high enough. These values in plant shoots were below the normal levels in plants (0.1-1 $\left.\mathrm{mg} \cdot \mathrm{kg}^{-1}\right)$, for Cd [26] only was exceeded by Carex tristachya in stems and leaves with a content of 2.28 and 1.63 $\mathrm{mg} \cdot \mathrm{kg}^{-1}$, respectively.

For $\mathrm{Cd}$ and $\mathrm{Cu}$, the highest concentrations in stems and leaves were determined in Carex tristachya, and the highest concentrations in roots were found in Cenchrus echinatus. The $\mathrm{Zn}$ concentrations were generally high for all the tested plants. The highest values for $\mathrm{Zn}$ were observed in leaves of Carex tristachya, and stems and roots of Echinochloa crusgalli. As for $\mathrm{Ni}$, the highest values were determined in all parts of Carex tristachya. Additionally, metal distribution in most plants decreased in the following order: root $>$ stem or leaf except for Carex tristachya, indicationg lower translocation capacities.

The potential of a plant species for phytoremediation depends on its inherent properties as large yield, rapid growth rate, high metal contents in its aboveground parts, and tolerance to various adverse environmental conditions, including heavy metals [27]. Compared with crops, weed species usually own these characteristics. The tolerance capabilities may be obtained through vacuolar compartmentalization, chelation of metals by some organic acids, and thereby minimization of the loss of biomass [15, 28-30]. The results presented indicate that $\mathrm{Cu}$ and $\mathrm{Zn}$ concentrations in all the investigated plant species were considerably higher compared to $\mathrm{Cd}$ and $\mathrm{Ni}$ concentrations. However, the $\mathrm{Cd}$, $\mathrm{Cu}$, and $\mathrm{Ni}$ contents in shoots (stems or leaves) were within the normal range (Cd 0.1-1 mg $\mathrm{kg}^{-1}, \mathrm{Cu} 3-20 \mathrm{mg} \cdot \mathrm{kg}^{-1}$, Ni 0.1$5 \mathrm{mg} \cdot \mathrm{kg}^{-1}$, respectively) for plants [13] except for Carex tristachya. The risk of entering into the food chain was highly reduced. The $\mathrm{Zn}$ concentrations in stems and leaves were much higher in relation to the normal values of 15-150 $\mathrm{mg} \cdot \mathrm{kg}^{-1}$ for plants [31], except for Setaria viridis.

Metal bioavailability relies not only on the form of the element but also on the plant species. In our study, the content in shoots of Carex tristachya of some metals $(\mathrm{Cd}, \mathrm{Cu}$, $\mathrm{Ni})$ was significantly higher than other plant species, indicating the occurrence of different mechanisms and its natural adaption to the contaminated compost. Based on the mean concentrations of $\mathrm{Cu}, \mathrm{Zn}, \mathrm{Cd}$, and $\mathrm{Ni}$ in the investigated plants except for Carex tristachya, it can be observed that metal contents in stems and leaves were lower compared to the concentration of the same elements in the roots, which is in agreement with the results observed by Antonijević et al. [32]. These results indicate main accumulation of metals in the roots. The mean concents of target metals in plant samples decrease in the following: $\mathrm{Zn}>\mathrm{Cu}>\mathrm{Ni}>\mathrm{Cd}$. This is probably attributed to different metal content in compost, diverse metal uptake mechanisms, and some disparities in their translocation abilities [33].
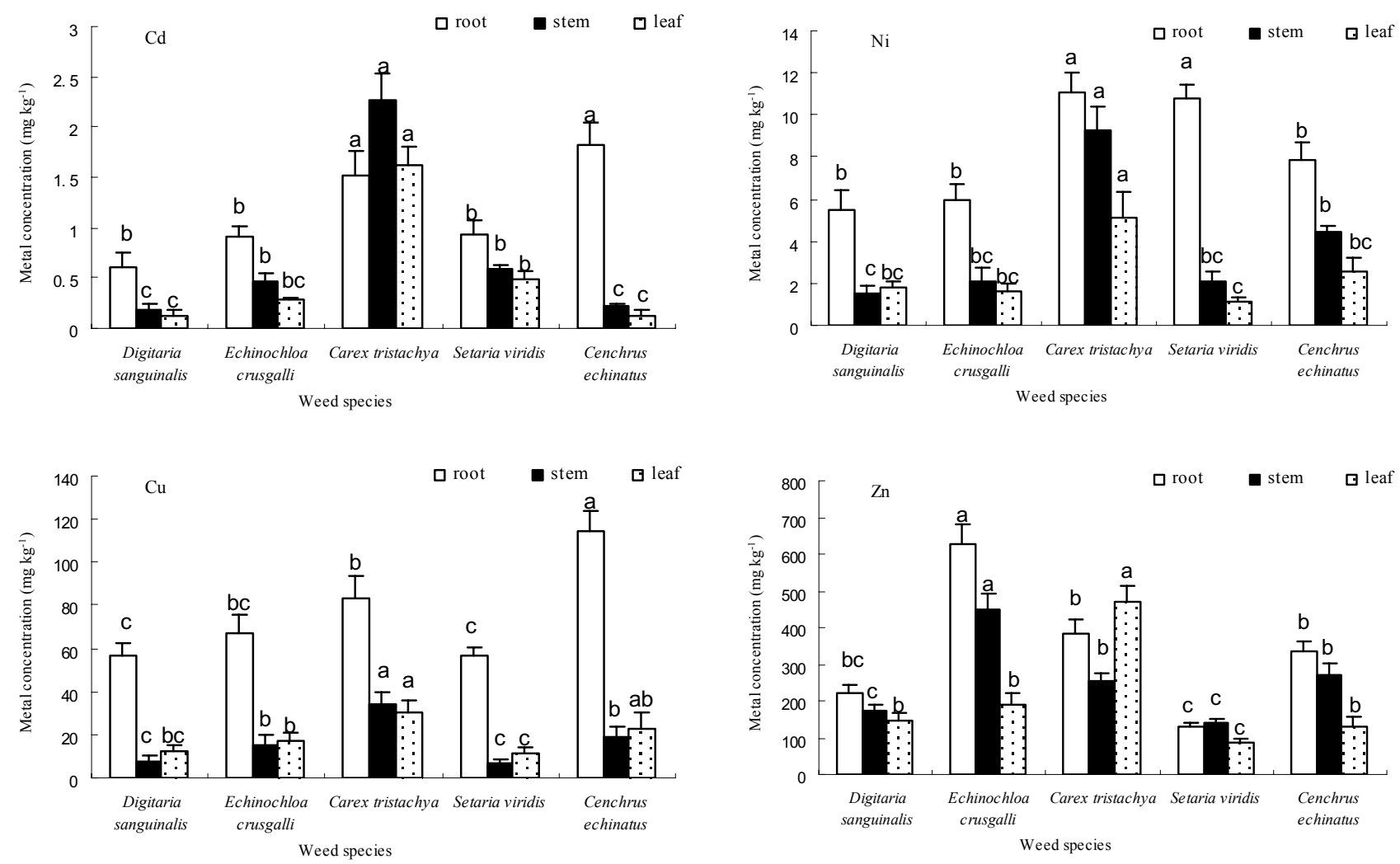

Fig. 1. Metal concentrations and distribution in five monocotyledonous weed species. Error bars represent SD triplicates. Different letters denote significant differences within the same part $(\mathrm{P}<0.05)$. 
Table 1. Heavy metal bioconcentration factors (BCF) in different parts of five weed species.

\begin{tabular}{|c|c|c|c|c|c|}
\hline \multirow{2}{*}{$\begin{array}{c}\text { Weed } \\
\text { species }\end{array}$} & \multirow{2}{*}{$\begin{array}{c}\text { Different } \\
\text { parts }\end{array}$} & \multicolumn{4}{|c|}{ Heavy metal BCF } \\
\cline { 3 - 6 } & $\mathrm{Cd}$ & $\mathrm{Cu}$ & $\mathrm{Zn}$ & $\mathrm{Ni}$ \\
\hline \multirow{3}{*}{$\begin{array}{c}\text { Digitaria } \\
\text { sanguinalis }\end{array}$} & Root & 0.46 & 0.19 & 0.48 & 0.21 \\
\cline { 2 - 6 } & Stem & 0.13 & 0.03 & 0.38 & 0.06 \\
\cline { 2 - 6 } & Leaf & 0.09 & 0.04 & 0.32 & 0.07 \\
\hline \multirow{3}{*}{$\begin{array}{c}\text { Echinochloa } \\
\text { crusgalli }\end{array}$} & Root & 0.68 & 0.22 & 1.38 & 0.23 \\
\cline { 2 - 6 } & Stem & 0.34 & 0.05 & 0.98 & 0.08 \\
\cline { 2 - 6 } $\begin{array}{c}\text { Carex } \\
\text { tristachya }\end{array}$ & Leaf & 0.22 & 0.06 & 0.42 & 0.06 \\
\cline { 2 - 6 } & Stem & 1.70 & 0.11 & 0.56 & 0.36 \\
\cline { 2 - 6 } & Leaf & 1.22 & 0.10 & 1.03 & 0.19 \\
\hline \multirow{3}{*}{$\begin{array}{c}\text { Setaria } \\
\text { viridis }\end{array}$} & Root & 0.70 & 0.19 & 0.28 & 0.41 \\
\cline { 2 - 6 } & Stem & 0.43 & 0.02 & 0.31 & 0.08 \\
\cline { 2 - 6 } & Leaf & 0.36 & 0.04 & 0.19 & 0.04 \\
\hline \multirow{3}{*}{$\begin{array}{c}\text { Cenchrus } \\
\text { echinatus }\end{array}$} & Root & 1.35 & 0.38 & 0.73 & 0.30 \\
\cline { 2 - 6 } & Stem & 0.17 & 0.06 & 0.59 & 0.17 \\
\cline { 2 - 6 } & Leaf & 0.09 & 0.08 & 0.28 & 0.1 \\
\hline
\end{tabular}

\section{Accumulation and Translocation of Metals in Plants}

Bioconcentration factor (BCF) and translocation factor (TF) have been used by many researchers to evaluate the ablity of plant to accumulate metal from soil [13, 32]. BCF is defined as the total metal concentration in the plant/total metal concentration in the soil, and TF is defined as the total metal in shoot/total metal in root. Plants can be classified as potential species for phytoextraction if $\mathrm{BCF}$ and TF are higher than one, whereas tolerant plants tend to restrict metal transfer from soil to root and root to shoot, and therefore accumulated less in their aboveground biomass [34-36]. Generally speaking, for all the investigated plant species, the $\mathrm{BCF}$ values of roots were found to be higher than that of shoots for most metals, implying that metals were easily

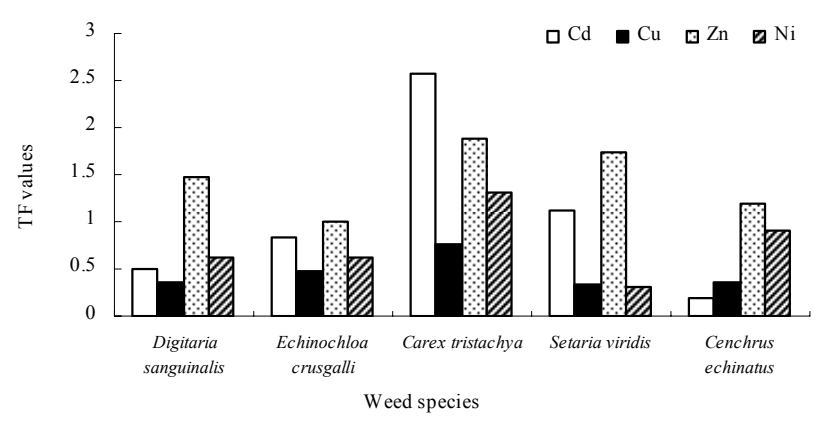

Fig. 2. Heavy metal translocation factor (TF) in five monocotyledonous weed species. accumulated in roots (Table 1). Nevertheless, the species Carex tristachya was characterized by BCF values higher than 1 of $\mathrm{Cd}$ in aerial parts ( 1.70 for stem and 1.22 for leave, respectively) due to a certain potential for uptake and translocation of $\mathrm{Cd}$. However, BCF values $<1$ were found for four other plant species. Similar to BCF, the maximum translocation factor $(\mathrm{TF}=2.56)$ for $\mathrm{Cd}$ was found for Carex tristachya, while four other species showed low TF values (Fig. 2). The TF values for all investigated plant species determined for $\mathrm{Zn}$ were higher than one, implying that $\mathrm{Zn}$ was easily tranfered from roots to shoots. Meanwhile, Echinochloa crusgalli and Cenchrus echinatus showed a positive potential for $\mathrm{Zn}$ and $\mathrm{Cd}$, respectively, and immobilization in the roots $(\mathrm{BCF}>1)$. Additionally, some tolerant plants with $\mathrm{BCF}$ and $\mathrm{TF}$ lower than one also behave as excluders by avoidance, because they have developed mechanisms allowing their growth in highly polluted soils [13]. Thus, considering tolerance, accumulation, BCF, and TF properties together, only Carex tristachya indicated Cdhyperaccumulative characteristics. Wei et al. also reported that some weed species displayed Cd- hyperaccumulative properties, such as Rorippa globosa, Conyza canadensis, Taraxacum mongolicum, and so on $[15,18]$. Considering the risk of heavy metals returning to the environment in the process of phytoextraction, plant shoots with accumulated heavy metals should be recovered and disposed of adequately.

\section{Conclusions}

The present research demontrates that total contents of metals in MSW compost generally exceeded the maxium levels indicated in Chinese regulations. The tested indigenous plants wildly growing in the studied area can grow well in contaminated MSW compost. This would be a great advantage if they are used in the revegetation of polluted sites. Based on the examination of five weed species for possible application of phytoextraction, only Carex tristachya has the potential for Cd phytoextraction from MSW compost. Other species can be considered adequate candidates for metal stabilization and soil conservation.

\section{Acknowledgements}

The authors are grateful to the Key Project of Tianjin Science and Technology for financial support (No. 13ZCZDNC00200).

\section{References}

1. ZHANG Y., SHANG X., LI K., ZHANG C., ZHANG K., RONG H. Technologies status and management strategies of municipal solid waste disposal in China. Ecol. Environ. Sci. 20, 389, 2011.

2. MOLDES A., CENDÓN Y., BARRAL M.T. Evaluation of municipal solid waste compost as a plant growing media component, by applying mixture design. Bioresour. Technol. 98, 3069, 2007. 
3. MONTEMURRO F., MAIORANA M. Nitrogen utilization, yield, quality and soil properties in a sugarbeet crop amended with municipal solid waste compost. Compost Sci. Util. 15, 84, 2007.

4. CHERIF H., AYARI F., OUZARI H., MARZORATI M., BRUSETTI L., JEDIDI N., HASSEN A., DAFFONCHIO D. Effects of municipal solid waste compost, farmyard manure and chemical fertilizers on wheat growth, soil composition and soil bacterial characteristics under Tunisian arid climate. Eur. J. Soil Biol. 45, 138, 2009.

5. FAGNANO M., ADAMO P., ZAMPELLA M., FIORENTINO N. Environmental and agronomic impact of fertilization with composted organic fraction from municipal solid waste: A case study in the region of Naples, Italy. Agr. Ecosyst. Environ. 141, 100, 2011.

6. TOPCUOĞLU B. Effects of repeated applications of sewage sludge and MSW compost on the bioavailability of heavy metals in greenhouse soil. Pol. J. Environ. Stud. 14, 217, 2005.

7. ACHIBA W.B., GABTENI N., LAKHDAR A., LAING G.D., VERLOO M., JEDIDI N., GALLALI T. Effects of 5year application of municipal solid waste compost on the distribution and mobility of heavy metals in a Tunisian calcareous soil. Agr. Ecosyst. Environ. 130, 156, 2009.

8. SMITH S.R. A critical review of the bioavailability and impacts of heavy metals in municipal solid waste composts compared to sewage sludge. Environ. Int. 35, 142, 2009.

9. GARBISU C., ALKORTA I. Phytoextraction: a cost-effective plant-based technology for the removal of metals from the environment. Bioresour. Technol. 77, 229, 2001.

10. PIOTROWSKA-CYPLIK A., CZARNECKI Z. Phytoextraction of heavy metals by hemp during anaerobic sewage sludge management in the non-industrial sites. Pol. J. Environ. Stud. 12, 779, 2003.

11. BROOKS R.R. Plants that hyperaccumulate heavy metals. CAB International, Wallingford, UK, 1998.

12. REEVES R.D. Tropical hyperaccumulators of metals and their potential for phytoextraction. Plant Soil 249, 57, 2003.

13. BRUNETTI G., SOLER-ROVIRA P., FARRAG K., SENESI N. Tolerance and accumulation of heavy metals by wild plant species grown in contaminated soils in Apulia region, Southern Italy. Plant Soil 318, 285, 2009.

14. ROBINSON B.H., MILLIS T.M., PETIT D., FUNG L.E., GREEN S.R., CLOTHIER B.E. Natural and induced cadmium-accumulation in poplar and willow: Implications for phytoremediation. Plant Soil 227, 301, 2000.

15. WEI S.H., ZHOU Q.X., XIAO H., YANG C.J., HU Y.H., REN L.P. Hyperaccumulative property comparison of 24 weed species to heavy metals using a pot culture experiment. Environ. Monit. Assess. 152, 299, 2009.

16. GHOSH M., SINGH S.P. A comparative study of cadmium phytoextraction by accumulator and weed species. Environ. Pollut. 133, 365, 2005.

17. WEI S.H., ZHOU Q.X., WANG X., CAO W., HU Y.H., REN L.P., SONG Y.F. Potential of weed species applied to remediation of soils contaminated with heavy metals. J. Environ. Sci. 16, 868, 2004.

18. WEI S.H., ZHOU Q.X., SAHA U.K. Hyperaccumulative characteristics of weed species to heavy metals. Water Air Soil Pollut. 192, 173, 2008.

19. MUHAMMAD S., SHAH M.T., KHAN S. Heavy metal concentrations in soil and wild plants growing around $\mathrm{Pb}-\mathrm{Zn}$ sulfide terrain in the Kohistan region, northern Pakistan. Microchem. J. 99, 67, 2011.

20. GUO J., REN G. Variation characteristics of sunshine duration in Tianjin in recent 40 years and influential factors. Meteorol. Sci. Technol. 34, 415, 2006.

21. JORDÃO C.P., NASCENTES C.C., CECON P.R., FONTES R.L.F., PEREIRA J.L. Heavy metal availability in soil amended with composted urban solid wastes. Environ. Monitor. Assess. 112, 309, 2006.

22. BAO S.D. Soil Physical and Chemical Analysis. Beijing: Chinese Agricultural Press, China, 2000.

23. PARKINSON J.A., ALLEN S.E. A wet oxidation procedure suitable for the determination of $\mathrm{N}$ and mineral nutrients in biological materials. Commun.Soil Sci. Plan., 6, 1, 1975.

24. KIEHL E. J. Fertilizantes Orgânicos, Agronômica Ceres, Piracicaba, Brasil, pp. 417, 1985.

25. SMITH S.R. A critical review of the bioavailability and impacts of heavy metals in municipal solid waste composts compared to sewage sludge. Environ. Int. 35, 142, 2009.

26. CHANEY R.L. Toxic accumulation in soils and crops: protecting soil fertility and agricultural food-chains. In: BARYOSEF B., BARROW N.J., GOLDSCHMID J. (Ed.): Inorganic Contaminants in the Vadose Zone. SpringerVerlag, Berlin, pp. 140, 1989.

27. LI P., WANG X., ZHANG T., ZHOU T., HE Y. Distribution and accumulation of copper and cadmium in soil-rice system as affected by soil amendments. Water Air Soil Poll. 196, 29, 2009.

28. ORTIZ D.F., RUSCITTI T., MCCUE K.F., OW D.W. Transport of metal-binding peptides by HMT1, a fission yeast ABCtype vacuolar membrane protein. J. Biol. Chem. 270, 4721, 1995.

29. HUANG J.W., CUNNINGHAM S.D. Lead phytoextraction: Species variation in lead uptake and translocation. New Phytol. 134, 75, 1996.

30. KRÄMER U., COTTER-HOWELLS J.D., CHAMOCK J.M., BAKER A.J.M., SMITH J.A.C. Free histidine as a metal chelator in plants that accumulate nickel. Nature 379, 635, 1996.

31. CHANEY R.L. Toxic accumulation in soils and crops: protecting soil fertility and agricultural food-chains. In: BARYOSEF B., BARROW N.J., GOLDSCHMID J. (Ed.): Inorganic Contaminants in the Vadose Zone. SpringerVerlag, Berlin, pp. 140, 1989.

32. ANTONIJEVIĆ M.M., DIMITRIJEVIĆ M.D., MILIĆ S.M., NUJKIĆ M.M. Metal concentrations in the soils and native plants surrounding the old flotation tailings pond of the copper mining and smelting complex bor (Serbia). J. Environ. Monit. 14, 866, 2012.

33. GREGER M. Metal availability, uptake, transport and accumulation in plants. In: PRASAD M.N.V. (Ed.): Heavy Metal Stress in Plants: from Biomolecules to Ecosystems. Springer, New York, pp. 1, 2003.

34. AHMAD A., GHUFRAN R., ZULARISAM A.W. Phytosequestration of metals in selected plants growing on a contaminated Okhla industrial areas, Okhla, New Delhi, India. Water Air Soil Pollut. 217, 255, 2011.

35. MENDEZ M.O., MAIER R.M. Phytoremediation of mine tailings in temperate and arid environments. Rev. Environ. Sci. Bio/Technol. 7, 47, 2008.

36. VAMERALI T., BANDIERA M., MOSCA G. Field crops for phytoremediation of metal-contaminated land: A review. Environ. Chem. Lett. 8, 1, 2010. 
